\title{
Hydrochemical evaluation of different spring waters for bottling
}

\author{
D. M. Bonotto, B. W. Tessari, L. Arthus, M. Santilli \\ \& L. Caprioglio \\ Departamento de Petrologia e Metalogenia, \\ Instituto de Geociências e Ciências Exatas-UNESP, Brazil
}

\begin{abstract}
This investigation was carried out within the Paraná sedimentary basin in São Paulo and Mato Grosso do Sul States, Brazil, and involved the sampling of different spring water samples with the purpose of evaluating their quality for bottling. Several methods were utilized for acquiring the hydrochemical data, such as methyl orange end-point titration, potentiometry, ion selective electrodes, spectrophotometry, atomic absorption spectrophotometry and inductively coupled plasma spectrometry. The results obtained for the analyzed samples were compared with the guideline values established by the São Paulo State and Brazilian Health Ministry legislations for defining the potable water standards. The Brazilian Code for Mineral Waters that was established by Register 7841 published on 8 August 1945 was also taken into account for verifying if the spring waters are mineralized. The hydrochemical data allowed the identification of anthropogenic and geogenic inputs of some constituents in most of the samples, which affected the water quality and did not allow them to be utilized for commercial purposes (bottling). The waters of these springs can only become appropriate for human consumption after previous chemical treatment.
\end{abstract}

Keywords: drinking water quality, spring waters, hydrochemistry, mineral waters, bottling, contamination.

\section{Introduction}

In many countries, spring waters are extensively used for consumption purposes as an option to tap water, as many people believe they are healthy and/or can be 
utilized for health cures. Additionally, economic reasons have also favored their use as bottled waters, so the commercialization of mineral waters has widely increased, for instance, by about 15\% per year in Brazil where circa 20 million consumers are involved [1]. The Brazilian Code for Mineral Waters was established by Register 7841 published on 8 August 1945 [2]. According to chemical aspects, the waters may be classified as follows:

-Radiferous: containing dissolved radioactive substances that sustain a permanent radioactivity;

-Bicarbonate-alkaline: containing dissolved alkaline compounds corresponding to a minimum of $0.2 \mathrm{~g}$ per liter of sodium bicarbonate;

-Earth-alkaline: containing dissolved earth-alkaline compounds corresponding to a minimum of $0.12 \mathrm{~g}$ per liter of sodium carbonate. They may be Ca-dominated if they contain at least $0.048 \mathrm{~g}$ per liter of $\mathrm{Ca}$ as calcium bicarbonate or $\mathrm{Mg}$ dominated if they contain at least $0.030 \mathrm{~g}$ per liter of $\mathrm{Mg}$ as magnesium bicarbonate.

-Sulfated: containing dissolved sulfate corresponding to a minimum of $0.1 \mathrm{~g}$ per liter combined with sodium, potassium and magnesium;

-Sulfured: containing dissolved sulfur corresponding to a minimum of $0.001 \mathrm{~g}$ per liter;

-Nitrated: containing dissolved nitrate of mineral origin corresponding to a minimum of $0.1 \mathrm{~g}$ per liter;

-Chlorinated: containing dissolved chloride corresponding to a minimum of $0.5 \mathrm{~g}$ per liter of sodium chloride;

-Ferruginous: containing dissolved iron corresponding to a minimum of $0.005 \mathrm{~g}$ per liter;

-Radioactive: containing dissolved radon according to three different levels, i.e. (a) weakly radioactive (radon content between 5 and 10 Mache Unit per liter),

(b) radioactive (radon content between 10 and 50 Mache Unit per liter) and (c) strongly radioactive (radon content higher than 50 Mache Unit per liter).

-Thoriferous: containing dissolved thoron corresponding to a minimum of 2 Mache Unit per liter;

-Carbogaseous: containing dissolved carbon dioxide gas corresponding to a minimum of $200 \mathrm{~mL}$ per liter at $20^{\circ} \mathrm{C}$ temperature and $760 \mathrm{mmHg}$ pressure.

The Brazilian mineral waters are also classified according to the temperature as follows [2]:

-Cold waters: temperature lower than $25^{\circ} \mathrm{C}$;

-Hypothermal waters: temperatures ranging from 25 to $33^{\circ} \mathrm{C}$;

-Mesothermal waters: temperatures ranging from 33 to $36^{\circ} \mathrm{C}$;

-Isothermal waters: temperatures ranging from 36 to $38^{\circ} \mathrm{C}$;

-Hyperthermal waters: temperature higher than $38^{\circ} \mathrm{C}$.

Many mineral springs around the world do not contain strong concentrations of minerals, and are thus classified as lightly mineralized, or oligomineral waters [3]. This is also the case for many spring waters utilized for drinking purposes in Brazil and attention must be paid to diverse problems related to the interaction between the society and environment as it may occur the introduction of constituents able to cause modification on the desirable water quality for 
consumption purposes. Thus, the spring waters must also be properly managed like others hydrological resources, particularly if the intention is their use as bottled waters. This paper describes the results of some hydrochemical monitoring held in different aquifer systems in order to evaluate the water quality. Because it has been analyzed different spring waters with the purpose of bottle them for human consumption, the Brazilian legislation was utilized for providing guideline values for drinking water quality.

\section{Analytical methods}

Several standard analytical techniques were used for obtaining the parameters analyzed in the water samples, for example, dilution and incubation method, evaporation, methyl orange end-point titration, potentiometry, ion selective electrode, spectrophotometry, atomic absorption spectrophotometry and inductively coupled plasma spectrometry. Portable meters were used for in situ determinations of temperature, $\mathrm{pH}$ and dissolved oxygen (DO). The $\mathrm{pH}$ measurement was performed by a digital portable meter coupled to a combination glass electrode; buffer solutions equilibrated with the sample temperature were utilized to calibrate the equipment before the analyses. The DO was determined in a pointer meter recording the potential values generated by an $\mathrm{O}_{2}$ sensible electrode consisting on a metallic wire covered by a thin layer of gold.

The true color for two water samples was determined by colorimetry (wavelength $455 \mathrm{~nm}$ ) after filtering the suspended materials and using a program stored in the Hach DR/2000 spectrophotometer that was calibrated in color units based on the APHA-recommended standard of 1 color unit being equal to $1 \mathrm{mg}$ $\mathrm{L}^{-1}$ platinum as chloroplatinate ion [4]. The same samples were analyzed for total coliforms through the fast ColiQuik Presence/Absence test [4] that utilizes a medium providing specific indicator nutrients, i.e. ONPG (o-nitrophenyl- $\beta$-dgalactopyranoside) and MUG (4-methylumbelliferyl- $\beta$-d-glucuronide).

A bench digital meter provided electrical conductivity readings obtained though a $1 \mathrm{~cm}^{2}$ area platinum electrode calibrated with $\mathrm{KCl}$ standards. The dry residue (DR) ( total dissolved solids, TDS) content was evaluated on evaporating the filtrate to dryness in a weighed flask that was dried to constant weight at $180^{\circ} \mathrm{C}$, with the increase in flask weight representing DR [5]. The alkalinity of the water samples was determined by titration using a titrator with sulfuric acid standard solution to an end point evidenced by the color change of a standard indicator solution [5]. The obtained values corresponded to alkalinity due to the presence of bicarbonate, carbonate and/or hydroxides.

The BOD (Biochemical Oxygen Demand) was measured by the dilution method, employing high purity distilled water provided by Barnstead Mega-Pure One Liter Water Still. For this purpose, the dissolved oxygen (DO) content remaining in six portions of each well-mixed sample transferred to separated 300-mL glass-stoppered bottles was evaluated after a five-day incubation period; the DO values measured potentiometrically were plotted against the $\mathrm{mL}$ of 


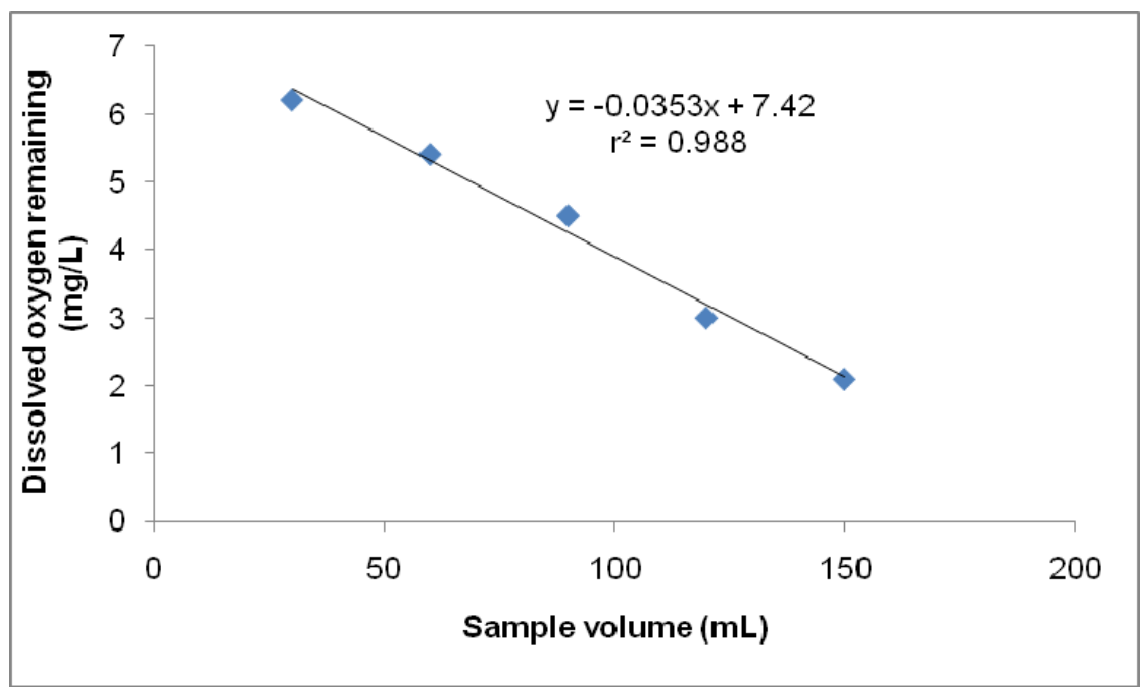

Figure 1: The dissolved oxygen values plotted against the sample volume for estimating the BOD (Biochemical Oxygen Demand).

sample taken, yielding a straight line that allowed obtain the BOD data [4]. Fig. 1 illustrates a typical straight line obtained for acquiring the results.

Calcium hardness (as $\mathrm{CaCO}_{3}$ ) and magnesium hardness (as $\mathrm{MgCO}_{3}$ ) of the water samples were determined by the colorimetric method (wavelength $522 \mathrm{~nm}$ ) after chelating calcium with EGTA and calcium and magnesium with EDTA [4], parameters that allowed to evaluate $\mathrm{Ca}$ and $\mathrm{Mg}$ contents. The analyses of dissolved sodium were done by flame photometry, whereas potassium was determined by the tetraphenylborate method that is based on the combination of $\mathrm{K}$ with sodium tetraphenylborate to form an insoluble white solid read at $650 \mathrm{~nm}$ [4].

Chloride and fluoride were measured potentiometrically after adding a known amount of ionic strength adjustor to each sample, when necessary. Orion ionselective electrodes coupled into a digital meter were used, where standards containing variable concentrations of chloride and fluoride were utilized for preparing calibration curves consisting on logarithmic straight lines involving the potential and concentration readings. Nitrate, nitrite, ammonium, phosphate and sulfate were determined by colorimetry [4] after adding reagents to the samples that are able to produce colored complexes read by a program stored in Hach $\mathrm{DR} / 2000$ spectrophotometer previously calibrated in variable concentrations at different wavelengths.

The metals $\mathrm{Ba}, \mathrm{Cr}, \mathrm{Cr}^{6+}$ and $\mathrm{Fe}$ were also measured colorimetrically. The amount of turbidity present in a fine white barium sulfate precipitate was read at $450 \mathrm{~nm}$ in order to supply the Ba concentration data. $\mathrm{Cr}^{6+}$ was determined on using 1,5-diphenylcarbohydrazide, which reacts to give a purple color read at $540 \mathrm{~nm}$ when $\mathrm{Cr}^{6+}$ is present. The 1,10 phenanthroline indicator formed an orange color in proportion to the iron concentration, which was read at $510 \mathrm{~nm}$. 
Other metals were measured by colorimetry, atomic absorption spectrophotometry and inductively coupled plasma spectrometry.

\section{The selected sites at São Paulo and Mato Grosso do Sul States in Brazil}

The methods described in previous item were applied to spring waters collected in areas situated at São Paulo and Mato Grosso do Sul States in Brazil. They are located at the following municipalities: Amambai in Mato Grosso do Sul State (site No. 1), Santa Rita do Passa Quatro in São Paulo State (Site No. 2) and São José do Rio Pardo in São Paulo State (Site No. 3) (Fig. 2). Two spring water samples were collected from different locations at São José do Rio Pardo municipality (Site No. 3). All sites are geologically situated at the Paraná sedimentary basin. The sedimentary sequence is almost undisturbed, with gentle dips towards the center of the basin, and covers since the Silurian-Devonian up to the Cretaceous periods. The major rock types [6] include sandstones, conglomerates, diamictites, siltstones, shales, mudstones, limestones, basalts and diabases that belong to Tubarão Group (Itararé Subgroup and Tatuí Formation), Passa Dois Group (Irati and Corumbataí Formations), São Bento Group (Pirambóia, Botucatu, and Serra Geral Formations), Bauru Group and different types of Cenozoic covers (Fig. 2).

Tietê River is the major drainage system at São Paulo State, which originates close to São Paulo city, cross the whole state, and discharges into Paraná River at the border with Mato do Grosso Sul State. Multiaquifer systems mainly comprising sandstones and basalts plus sediments from Passa Dois Group behaving as aquitards have been proposed to represent the hydrostratigraphy of the Paraná basin [7]. Groundwater occurs within the interflow zones and along cooling joints in basalts and diabases from Serra Geral Formation. The sandstones of Cretaceous age (Bauru Group) are moderately cemented and exhibit adequate properties to storage water. The Paleozoic sediments (Devonian-Permian age) also provide water that is relatively mineralized in the central parts of the basin and contains $\mathrm{H}_{2} \mathrm{~S}$ in some wells. The Guarani aquifer corresponds to sediments (Triassic-Jurassic age) consisting of silty and shaly sandstones of fluvial-lacustrine origin (Pirambóia Formation) and variegated quartzitic sandstones accumulated by eolian processes under desert conditions (Botucatu Formation). It has continental dimensions [7], extends over some $950,000 \mathrm{~km}^{2}$ within the Paraná sedimentary basin, has an average thickness of 300-400 m, overlies formations ranging from the igneous basement to Paleozoic sediments of the Passa Dois and Tubarão Groups, and is covered by a thick (up to $1,500 \mathrm{~m}$ ) basaltic package of Serra Geral Formation and Cretaceous sediments of the Bauru Group (Fig. 2).

Spring water samples for chemical analysis were collected at farms whose owners intended to bottle them for commercial purposes. Thus, they had to know the water quality for this purpose. The water discharge occurred through cracks, joints and faults from rocks outcropping in the Paraná sedimentary basin. The water samples $(\sim 5 \mathrm{~kg})$ were stored in polyethylene bottles and, depending on the 


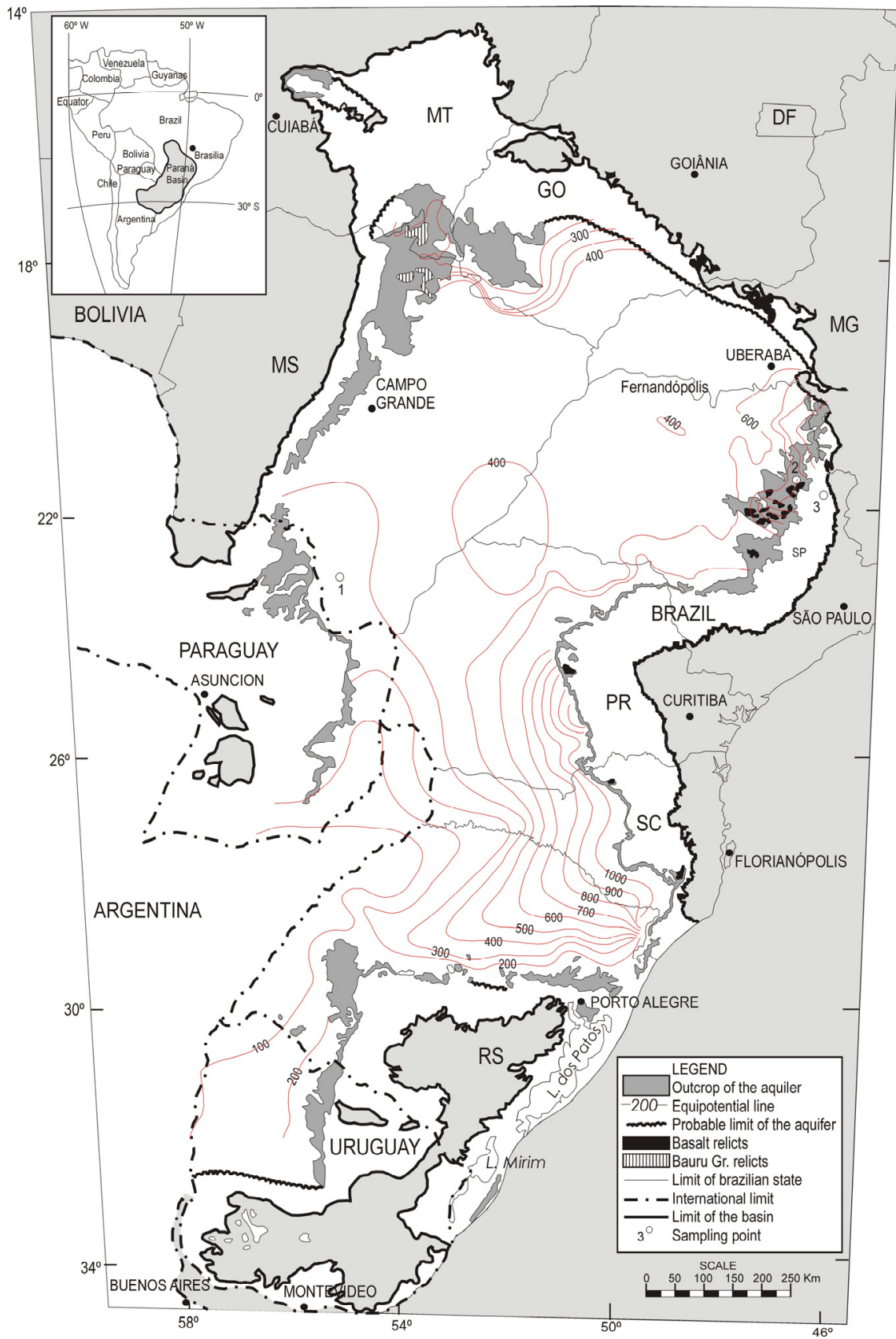

Figure 2: A simplified geological map of the Paraná sedimentary basin, the general groundwater flow in the Guarani aquifer according to [7] and the location of the sampling sites for spring waters. 
Table 1: $\quad$ Results of the analyses of spring waters from the studied sites.

\begin{tabular}{cccccc}
\hline PARAMETER & UNIT & SITE & SITE & SITE & SITE \\
& & No. 1 & No. 2 & No. 3(a) & No. 3(b) \\
\hline Sampling date & - & May 1995 & Feb. 1995 & July 1997 & Aug. 1997 \\
Discharge & L/day & - & 17,280 & - & - \\
Temperature & ${ }^{\circ}$ & - & 26 & - & - \\
Color & Pt-Co & 2 & 2 & 10 & 0 \\
Odor & - & Absent & Absent & Absent & Absent \\
Turbidity & NTU & 0 & 0 & 2 & 0 \\
pH & - & 7.0 & 6.0 & 5.8 & 6.1 \\
Conductivity & $\mu \mathrm{S} / \mathrm{cm}$ & 162 & 22.3 & 150 & 200 \\
Free CO 2 & $\mathrm{~mL}$ & 0.03 & - & - & - \\
Dry Residue & $\mathrm{mg} / \mathrm{L}$ & 42 & 78 & 75 & 100 \\
Settleable solids & $\mathrm{mL} / \mathrm{L}$ & 0.0 & 0.0 & - & - \\
Dissolved Oxygen & $\mathrm{mg} / \mathrm{L}$ & - & 7.0 & - & - \\
BOD & $\mathrm{mg} / \mathrm{L}$ & - & - & 4.0 & 0.4 \\
Total coliforms & $\mathrm{n} / 100 \mathrm{~mL}$ & - & 16 & Present & Present \\
Standard counting & $\mathrm{colonies/}$ & - & 3,485 & - & - \\
of bacteria & $\mathrm{mL}$ & & & & \\
\hline${ }^{1}$ BOD $=$ Biochemical Oxygen Demand (5 days, $\left.20^{\circ} \mathrm{C}\right)$. & &
\end{tabular}

requirements of the analysis, they were separated as unfiltered and unpreserved, filtered through $0.45 \mu \mathrm{m}$ membranes and preserved with different acids, etc.

\section{Hydrochemical analyses and water quality}

The results obtained for the analyzed samples are reported in Tables 1 and 2 and compared with guideline values established by two different legislation (Table 3): Register 25 of the National Commission of Rules and Standards for Food of the Health Ministry published on 1976and Rule No. 12486 (NTA60) established in $20^{\text {th }}$ October 1978 by São Paulo State for defining the potable water standards.

The data reported in Tables 1 and 2 for Site No. 1 were compared with the guideline values given in Table 3(a), as well with the Brazilian Code for Mineral Waters. The available data do not allow classify these spring waters as mineral waters, however, they are appropriate for human consumption (potable) and can be classified as "of natural spring". The data for major ions in sample collected at Site No. 2 were plotted on a Piper [8] diagram. Fig. 3 shows that these waters are bicarbonated and mixed in terms of major cations. When the data obtained for these waters are compared with the guideline values given in Table 3(a) and also with the Brazilian Code for Mineral Waters, it is again not possible classify them as mineral waters. The reference values reported in Table 3(b) allow evaluate if these waters are potable and this is not the case in terms of the microbiological aspects as the number of total coliforms per $100 \mathrm{~mL}$ of sample is not absent. On the other hand, such water source could be chemically treated (for instance, by chlorination) in order to become potable, however, under such 
Table 2: $\quad$ Results of the analyses of spring waters from the studied sites.

\begin{tabular}{|c|c|c|c|c|c|}
\hline PARAMETER & UNIT & $\begin{array}{l}\text { SITE } \\
\text { No. } 1 \\
\end{array}$ & $\begin{array}{l}\text { SITE } \\
\text { No. } 2 \\
\end{array}$ & $\begin{array}{c}\text { SITE } \\
\text { No. 3(a) }\end{array}$ & $\begin{array}{c}\text { SITE } \\
\text { No. 3(b) }\end{array}$ \\
\hline Sodium & $\mathrm{mg} / \mathrm{L}$ & 2.1 & 0.5 & 0.2 & 1.4 \\
\hline Potassium & $\mathrm{mg} / \mathrm{L}$ & 21.2 & 1.3 & 5.1 & 5.0 \\
\hline Calcium & $\mathrm{mg} / \mathrm{L}$ & 11.1 & 1.2 & 0.1 & 0.1 \\
\hline Magnesium & $\mathrm{mg} / \mathrm{L}$ & 1.9 & 0.4 & 0.7 & 0.7 \\
\hline Total Alkalinity & $\mathrm{mg} / \mathrm{L}$ & 8.5 & 12.0 & 20 & 52 \\
\hline Hydroxide alkalinity & $\mathrm{mg} / \mathrm{L}$ & - & - & 0 & 0 \\
\hline Carbonate alkalinity & $\mathrm{mg} / \mathrm{L}$ & - & - & 0 & 0 \\
\hline Bicarbonate alkalinity & $\mathrm{mg} / \mathrm{L}$ & - & - & 20 & 52 \\
\hline Chloride & $\mathrm{mg} / \mathrm{L}$ & 1.0 & 0.6 & 1.3 & 0.8 \\
\hline Nitrate & $\mathrm{mg} / \mathrm{L}$. & 0.1 & 0.01 & 12.3 & 2.6 \\
\hline Nitrite & $\mathrm{mg} / \mathrm{L}$ & - & - & 0.02 & 0.01 \\
\hline Ammonium & $\mathrm{mg} / \mathrm{L}$ & - & - & 0.26 & 0.01 \\
\hline Sulfate & $\mathrm{mg} / \mathrm{L}$ & 0.1 & 0.03 & 0.1 & 0.1 \\
\hline Fluoride & $\mathrm{mg} / \mathrm{L}$ & 0.03 & 0.01 & 2.6 & 2.6 \\
\hline Aluminum & $\mathrm{mg} / \mathrm{L}$ & 0.2 & 0.05 & - & - \\
\hline Phosphate & $\mathrm{mg} / \mathrm{L}$ & 0.56 & - & - & - \\
\hline Barium & $\mathrm{mg} / \mathrm{L}$ & 0.02 & 0.06 & - & 1.0 \\
\hline Boron & $\mathrm{mg} / \mathrm{L}$ & $<0.02$ & $<0.02$ & - & - \\
\hline Cadmium & $\mathrm{mg} / \mathrm{L}$ & $<0.05$ & $<0.05$ & - & - \\
\hline Lead & $\mathrm{mg} / \mathrm{L}$ & $<0.10$ & $<0.10$ & - & - \\
\hline Copper & $\mathrm{mg} / \mathrm{L}$ & $<0.05$ & $<0.05$ & 0.08 & 0.13 \\
\hline Hexavalent chromium & $\mathrm{mg} / \mathrm{L}$ & - & - & - & 0.01 \\
\hline Total chromium & $\mathrm{mg} / \mathrm{L}$ & $<0.05$ & 0.03 & - & - \\
\hline Iron & $\mathrm{mg} / \mathrm{L}$ & $<0.05$ & $<0.05$ & 0.48 & 0.16 \\
\hline Phosphorus & $\mathrm{mg} / \mathrm{L}$ & 0.2 & 0.008 & - & - \\
\hline Manganese & $\mathrm{mg} / \mathrm{L}$ & $<0.02$ & $<0.02$ & 0.68 & 0.96 \\
\hline Tin & $\mathrm{mg} / \mathrm{L}$ & - & $<0.01$ & - & - \\
\hline Titanium & $\mathrm{mg} / \mathrm{L}$ & - & 0.08 & - & - \\
\hline Silicon & $\mathrm{mg} / \mathrm{L}$ & 5.7 & 6.11 & - & - \\
\hline Zinc & $\mathrm{mg} / \mathrm{L}$ & $<0.02$ & $<0.02$ & 2.1 & 2.1 \\
\hline
\end{tabular}

circumstance, it no more could be considered as "of natural spring" for commercial purposes (bottling). Its discharge corresponding to $17,280 \mathrm{~L} /$ day is lower than that of several traditional bottlers in São Paulo State, but is higher than that of many others which had been already established since 1976 (Table 5).

The data reported in Tables 1 and 2 for Sites No. 3(a) and 3(b) were compared with the guideline values given in Table 3(a), as well with the Brazilian Code for Mineral Waters. The available data do not allow classify these spring waters as mineral waters. They are also not appropriate for human consumption (potable) as some compounds like nitrate, ammonium, manganese and fluoride exhibited values that exceeded the maximum established by the referred legislation. Additionally, the presence of total coliforms was also 
Table 3: Parameters established by (a) Register 25 of the National Commission of Rules and Standards for Food of the Health Ministry published on 1976 and (b) Rule No. 12486 (NTA60) published in $20^{\text {th }}$ October 1978 by São Paulo State.

\begin{tabular}{cccc}
\hline PARAMETER & UNIT & VALUE (a) & VALUE (b) \\
\hline Color & $\mathrm{Pt}-\mathrm{Co}$ & $<5 \mathrm{mg} / \mathrm{L}$ & $10-20 \mathrm{mg} / \mathrm{L}$ \\
Odor & - & Absent & Absent \\
Turbidity & $\mathrm{NTU}$ & $<3$ & $2-5$ \\
Dry Residue & $\mathrm{mg} / \mathrm{L}$ & $<1500$ & $<500$ \\
$\mathrm{pH}$ & - & from 4 to 9 & from 5 to 9 \\
Consumed Oxygen - acid & $\mathrm{mg} / \mathrm{L}$ & $<4.5$ & $<2.5$ \\
$\mathrm{~N}_{2}$-ammonium & $\mathrm{mg} / \mathrm{L}$ & $<0.03$ & - \\
Nitrate & $\mathrm{mg} / \mathrm{L}$ & - & $<10$ \\
Chloride & $\mathrm{mg} / \mathrm{L}$ & $<100$ & $<250$ \\
Fluoride & $\mathrm{mg} / \mathrm{L}$ & $<1$ & $<1$ \\
Sulfate & $\mathrm{mg} / \mathrm{L}$ & - & $<250$ \\
Arsenic & $\mathrm{mg} / \mathrm{L}$ & $<0.05$ & $<0.05$ \\
Barium & $\mathrm{mg} / \mathrm{L}$ & $<1$ & $<1$ \\
Cadmium & $\mathrm{mg} / \mathrm{L}$ & $<0.01$ & $<0.01$ \\
Lead & $\mathrm{mg} / \mathrm{L}$ & $<0.05$ & $<0.05$ \\
Cyanide & $\mathrm{mg} / \mathrm{L}$ & $<0.2$ & $<0.2$ \\
Copper & $\mathrm{mg} / \mathrm{L}$ & $<1$ & $<1$ \\
Hexavalent chromium & $\mathrm{mg} / \mathrm{L}$ & $<0.05$ & $<0.05$ \\
Mercury & $\mathrm{mg} / \mathrm{L}$ & $<0.001$ & - \\
Total iron & $\mathrm{mg} / \mathrm{L}$ & - & $<0.3$ \\
Manganese & $\mathrm{mg} / \mathrm{L}$ & $<0.05$ & $<0.05$ \\
Selenium & $\mathrm{mg} / \mathrm{L}$ & $<0.01$ & $<0.01$ \\
Zinc & $\mathrm{mg} / \mathrm{L}$ & $<5$ & $<5$ \\
Total coliforms & $\mathrm{n} / 100 \mathrm{~mL}$ & - & $\mathrm{Absent}$ \\
Escherichia coli & $100 \mathrm{~mL}$ & $\mathrm{Absent}$ & - \\
\hline & & &
\end{tabular}

identified and confirmed by the BOD data. Therefore, such water sources cannot be utilized for human consumption without previous chemical treatment, implying that they could not be considered as "of natural spring" for commercial purposes.

The presence of total coliforms, N-compounds, fluoride and manganese as pollutants in spring waters occurring in São Paulo State, Brazil, do not allow utilize them for commercial purposes (bottling). Despite some constituents may be typically geogenic, local anthropogenic influences due to non-appropriate management of the recharge area related to the springs may be responsible by the contamination of shallower aquifers. As a consequence of such diffuse pollution, the water quality becomes non-appropriate for human consumption without previous chemical treatment. This also implies on the water usage by bottlers and others users, which are requested to direct efforts on the protection and conservation of the soil covers and vegetation for avoiding the water pollution. 


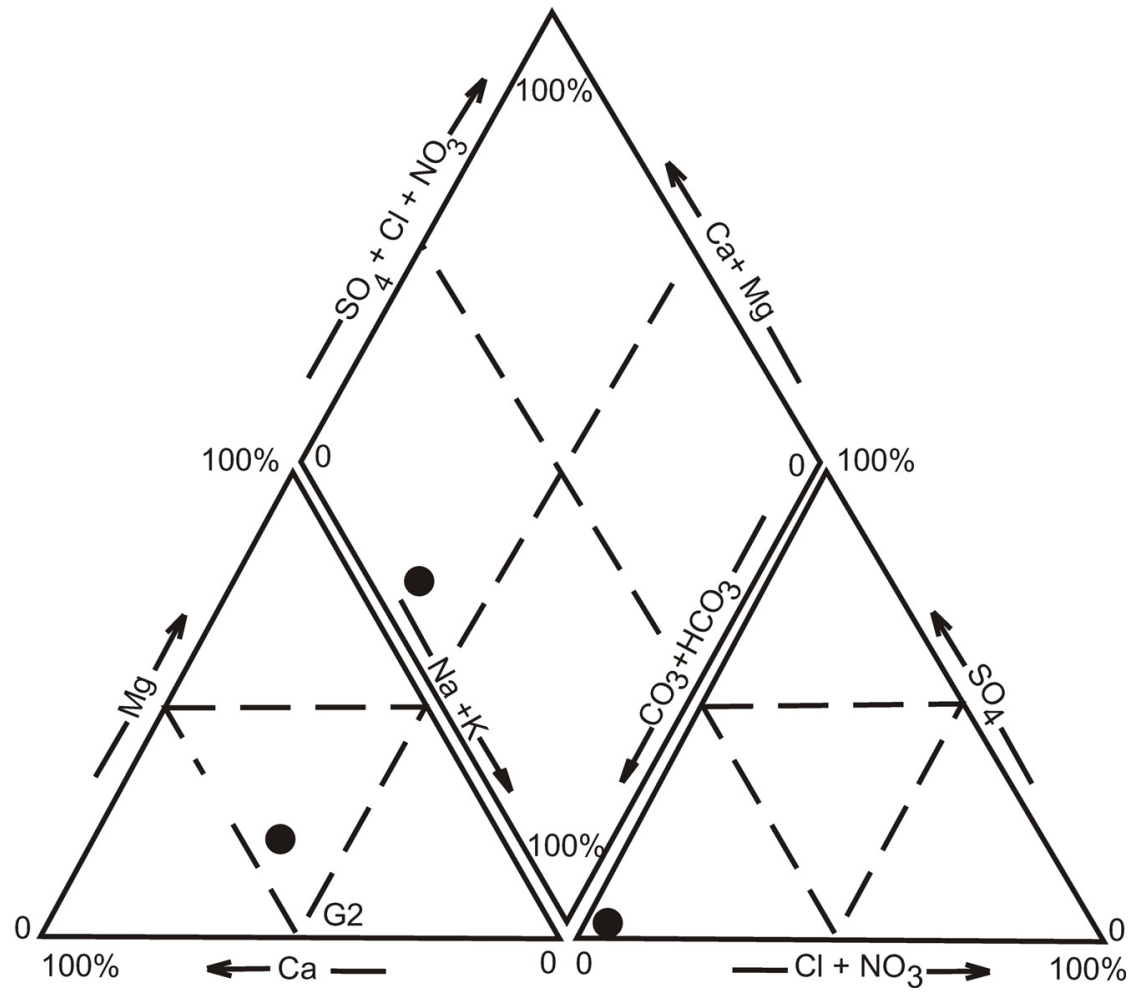

Figure 3: Major chemical data of the spring waters collected at Site No. 2 plotted on a Piper diagram.

Table 4: Discharge of springs located in São Paulo State that have had bottled waters since 1976 for supplying potable water classified as "of natural spring".

\begin{tabular}{cccc}
\hline City & Location & Spring name & Discharge (L/day) \\
\hline Analândia & Moinho Velho & $\begin{array}{c}\text { Santo Antônio } \\
\text { de Analândia }\end{array}$ & 5,000 \\
Oswaldo Cruz & Chácara & Oswaldo Cruz & 3,200 \\
Pugawara & Sítio Primavera & Primavera & 7,860 \\
São José do Rio & Jardim Conceição & No. 1 & 14,400 \\
Preto & Vila Alípia & Petrópolis & 8,000 \\
São Paulo & Bairro Tremembé & Nova & 3,500 \\
São Paulo & Jardim Conceição & No. 1 & 14,400 \\
São Simão & & &
\end{tabular}




\section{Acknowledgement}

The CNPq (National Council for Scientific and Technologic Development) in Brazil is thanked for financial support of this investigation.

\section{References}

[1] Comércio de água mineral; SEBRAE, Online. www.sebraesc.com.br/ideais/default.asp?vcdtexto $=31586 \& \% 5 \mathrm{E} \% 5 \mathrm{E}$

[2] DFPM (Division for Supporting the Mineral Production), The mining code, the mineral waters code and how applying research in a mineral deposit. $8^{\text {th }}$ edn., DFPM: Rio de Janeiro, 1966.

[3] Altman, N., Healing springs, Healing Arts Press: Rochester, 2000.

[4] HACH, Water Analysis Handbook, $2^{\text {nd }}$ edn., Hach Company: Loveland, 1992.

[5] APHA (American Public Health Association), Standard methods for the examination of water and wastewater. $17^{\text {th }}$ edn, Washington, 1989.

[6] Almeida, F.F.M. \& Melo, M.S., A bacia do Paraná e o vulcanismo Mesozóico. Mapa geológico do estado de São Paulo, ed. IPT (Instituto de Pesquisas Tecnológicas do Estado de São Paulo), Promocet: São Paulo, v. 1, pp. 46-81, 1981.

[7] Araújo, L.M., Franca, A.B. \& Potter, P.E., Hydrogeology of the Mercosul aquifer system in the Paraná and Chaco-Parana Basins, South America, and comparison with the Navajo-Nugget aquifer system, USA. Hydrogeology Journal, 7, pp. 317-336, 1999.

[8] Piper, A.M., A graphic procedure in the geochemical interpretation of wateranalyses. Eos Trans. $A G U, \mathbf{2 5}$, pp. 914-928, 1944. 